\title{
Antibiotic Resistant Genes in Various Environments
}

\author{
Hyun Min Jang ${ }^{1}$ and Eunsung Kan ${ }^{1,2 *}$ \\ ${ }^{1}$ Texas A\&M AgriLife Research Center, USA
}

${ }^{2}$ Department of Wildlife, Sustainability and Ecosystem Sciences, Tarleton State University, USA

Submission: September 04, 2018, Published: September 18, 2018

*Corresponding author: Eunsung Kan, Texas A\&M AgriLife Research Center, 1229 North US Highway 281, Stephenville, TX 76401, USA.

\begin{abstract}
This mini-review addresses occurrence, fate, mechanisms and possible remediation of antibiotic resistant genes in various environments. While antibiotic resistant genes are widely spread via multiple mechanisms, they often cause various diseases and significantly influence on human health. Wastewater treatment plants among various environmental matrices are considered as the main reservoir of antibiotic resistant genes. Current wastewater treatment technologies have revealed the limitations for effective treatment of antibiotic resistance at wastewater treatment plants. Thus, innovative and cost-effective means to reduce antibiotic resistance in wastewater needs to be developed.
\end{abstract}

Keywords: Antibiotics; Antibiotic resistance genes; Human health; Human bacterial pathogens

Abbreviations: ARGs: Antibiotic Resistance Genes; HGT: Horizontal Gene Transfer; WWTPs: Wastewater Treatment Plants; CWs: Constructed Wetlands

\section{Introduction}

Since the penicillin was discovered by Fleming [1], over 250 different antibiotics are registered for use in human and veterinary medicine [2]. A lot of antibiotics including tetracyclines, quinolones and sulfonamides have been extensively used for the prevention and treatment of human and animal diseases [3]. However, low metabolic efficiencies of antibiotics have led to negative effects on human and animal health. As reported by Daughton \& Ternes [4], most of the ingested antibiotics were excreted through urines and feces [5]. The undigested antibiotics were released to groundwater, wastewater, surface water and soil [6,7], while they often caused biotoxicity and antibiotic resistance in environments.

Unlike other pharmaceutical compounds, antibiotics are selectively act on bacteria via various mechanisms [8]. For example, antibiotics can inhibit the synthesis of cell wall and enzyme as well as protein [9]. However, some bacteria can be intrinsically resistant to one or multiple antibiotics through following molecular mechanisms [10]:
a. Changes in antibiotic targets by mutation.
b. Modification of targets.
c. Direct modification of antibiotics.

d. Prevention of access to target (e.g., efflux pump). All genes related to the antibiotic resistance are called "Antibiotic resistance genes (ARGs)".

In ecosystems, ARGs can persist over many generations and enable to proliferate by not only vertical transfer but also horizontal gene transfer (HGT) such as conjugation and transduction [11]. Accordingly, more recent attention has focused on the fate of ARGs in environment due to it is undoubtedly threaten human and animal health directly $[12,13]$. For instance, in US, at least 23,000 people die each year as a direct result of these antibiotic-resistant infections [14].

Several extensive literatures have reported the fate of ARGs in various environment matrices such as soil [15-18], ocean $[19,20]$, river $[21,22]$, and wastewater treatment plants (WWTPs) $[23,24]$. Among them, WWTPs is one of the largest reservoirs of ARGs and plays a significant role in the proliferation of ARGs to the environment [25-27]. Especially, environmental conditions including high microbial density and diversity in WWTPs may promote the HGT of ARGs with abundant mobile genetic elements [28]. Recent studies have revealed that the negative effects of effluent from WWTPs on received environments [29,30]. For this reason, tertiary process which may present an opportunity to minimize the expose of ARGs to the environment and ultimately reduce the risk of antibiotic-resistant infections in human $[11,31]$.

Several methods have been proposed for the removal of various antibiotics from water: biological treatment, advanced oxidation, membrane separation, and adsorption [32-38]. Unfortunately, these conventional water treatment processes do not remove antibiotics completely owing to the low concentrations and biorefractory properties of these contaminants $[39,40]$. Current biological treatments use the most economical means available, but they require a prolonged period of time to degrade antibiotics. Poor and inconsistent removal efficiencies of antibiotics are 
another drawback [41,42]. Advanced oxidation methods (e.g., using ozone, $\mathrm{H}_{2} \mathrm{O}_{2} / \mathrm{UV}$, Fenton oxidation $\left[\mathrm{Fe} / \mathrm{H}_{2} \mathrm{O}_{2}\right]$ and photocatalytic oxidation) remove emerging contaminant by utilizing strongly oxidizing hydroxy radicals [43-49]. Although these systems can achieve complete degradation of antibiotics [50,51], the short lifetime of the hydroxyl radicals necessitates the use of large amounts of oxidant to degrade trace levels of contaminants, which in turn degrades other organic compounds and generates metabolites of unknown toxicity [32,52]. Membrane separation is a promising technology for removal of micropollutants in water, however, it easily suffers from (bio)fouling problems which could result in unexpected interruption of contaminant treatment.

Interestingly, DNA and RNA can be damage when it exposed to hydroxy radicals [53]. In this respect, ozone, chlorination and photocatalytic oxidation have been applied for the removal of ARGs [54]. In addition, some studies were also extended to UV irradiation for the removal of ARGs [3,55]. For instance, Zhuang et al. [56], reported that $2.98-3.24,2.48-2.74$ and $1.68-2.55$ $\log$ reductions of ARGs were achieved by chlorination (dose of $160 \mathrm{mg} / \mathrm{L}$ with contact time of $120 \mathrm{~min}$ ), UV irradiation (UV dose of $12,477 \mathrm{~mJ} / \mathrm{cm}^{2}$ ) and ozonation (ozonation dose of $177.6 \mathrm{mg} / \mathrm{L}$ ), respectively. Although the ozone, chlorination and UV processes showed high removal of ARGs in a short time, they require high costs associated with energy and chemical consumption, maintenance and equipment. Recently, constructed wetlands (CWs) has been applied for the removal of antibiotics as well as ARGs due to its lower cost, easy operation and less maintenance requirements. In a positive sense, Huang et al. [57], reported that the removal efficiencies of ARGs in swine wastewater were greatly reduced with their removal efficiency ranging from 58 to $99.9 \%$ after vertical up-flow CWs treatment. However, increase in ARGs (e.g., tetracycline and sulfonamide resistance genes) was observed after horizontal and vertical subsurface flow CWs [58]. Thus, further study is needed to investigate the relationship between the operating conditions and ARGs in CWs as well as other treatment processes $[59,60]$.

\section{Discussion}

A growing evidence indicate the importance of proper control of ARGs in WWTPs. However, there is still insufficient information available regarding the tertiary processes which can effectively remove the ARGs in effluent of WWTPs. More cost effective and efficient treatment processes for complete control of ARGs in wastewater should be developed along with detailed mechanisms and biotoxicity. In addition, long-term tracing of ARGs in the received environment (e.g., river and soil) after tertiary processes should be conducted since the regulation of level of ARGs is still questionable.

\section{Conclusion}

A lot of antibiotics have been released to various environments and led to develop antibiotic resistance causing serious health problems. Particularly, antibiotic resistant genes (ARGs) are widely spread over soil, water and air via multiple mechanisms while negatively influencing on human health. Since wastewater treatment plants are the major sink of ARGs, various remediation technologies such as ultraviolet light, ozone, chlorination and biological treatment have been applied to reduction of ARGs in wastewater. However, these technologies have shown limitations to effectively remove ARGs in wastewater. Therefore, innovative and cost-effective technologies for reduction of ARGs in wastewater need to be developed.

\section{Acknowledgement}

This work was supported by Texas A\&M University Chancellor Research Initiative Fund.

\section{References}

1. Fleming A (1944) The Discovery of Penicillin. British Medical Bulletin 2(1): 4-5.

2. Kümmerer K, Henninger A (2003) Promoting resistance by the emission of antibiotics from hospitals and households into effluent. Clin Microbiol Infect 9(12): 1203-1214.

3. Pang Y, Huang J, Xi J, Hu H, Zhu Y (2016) Effect of ultraviolet irradiation and chlorination on ampicillin-resistant Escherichia coli and its ampicillin resistance gene. Frontiers of Environmental Science \& Engineering 10(3): 522-530.

4. Daughton CG, Ternes TA (1999) Pharmaceuticals and personal care products in the environment: agents of subtle change? Environ Health Perspect 107(Suppl 6): 907-938.

5. Winckler C, Grafe A (2001) Use of veterinary drugs in intensive animal production. Journal of Soils and Sediments 1(2): 66.

6. Halling-Sørensen B, Nors Nielsen S, Lanzky PF, Ingerslev F, Holten Lützhøft HC, et al. (1998) Occurrence, fate and effects of pharmaceutical substances in the environment- A review. Chemosphere 36(2): 357393.

7. Tolls J (2001) Sorption of veterinary pharmaceuticals in soils: a review. Environ Sci Technol 35(17): 3397-3406.

8. Sköld O (2011) Antibiotics and antibiotic resistance. John Wiley \& Sons.

9. Madigan MT, Martinko JM, Parker J (1997) Brock biology of microorganisms. Prentice hall Upper Saddle River, NJ, UK.

10. Blair JM, Webber MA, Baylay AJ, Ogbolu DO, Piddock LJ (2015) Molecular mechanisms of antibiotic resistance. Nat Rev Microbiol 13(1): 42-51.

11. Dodd MC (2012) Potential impacts of disinfection processes on elimination and deactivation of antibiotic resistance genes during water and wastewater treatment. J Environ Monit 14(7): 1754-1771.

12. Pruden A, Larsson DJ, Amézquita A, Collignon P, Brandt KK, et al. (2013) Management options for reducing the release of antibiotics and antibiotic resistance genes to the environment. Environ Health Perspect 121(8): 878-885.

13. Wright GD (2010) Antibiotic resistance in the environment: a link to the clinic? Curr Opin Microbiol 13(5): 589-594.

14. CDC (2013) Antibiotic resistance threats in the United States, 2013. US Department of Health Human Services.

15. Esiobu N, Armenta L, Ike J (2002) Antibiotic resistance in soil and water environments. Int J Environ Health Res 12(2): 133-144.

16. Donato JJ, Moe LA, Converse BJ, Smart KD, Berklein FC, et al. (2010) Metagenomic analysis of apple orchard soil reveals antibiotic resistance genes encoding predicted bifunctional proteins. Appl Environ Microbiol 76(13): 4396-4401. 
17. Heuer H, Schmitt H, Smalla K (2011) Antibiotic resistance gene spread due to manure application on agricultural fields. Curr Opin Microbiol 14(3): 236-243.

18. Knapp CW, Dolfing J, Ehlert PA, Graham DW (2009) Evidence of increasing antibiotic resistance gene abundances in archived soils since 1940. Environmental science \& technology 44(2): 580-587.

19. Chen B, Yang Y, Liang X, Yu K, Zhang T, et al. (2013) Metagenomic profiles of antibiotic resistance genes (ARGs) between human impacted estuary and deep ocean sediments. Environ Sci Technol 47(22): 12753-12760.

20. Hatosy SM, Martiny AC (2015) The ocean as a global reservoir of antibiotic resistance genes. Applied and environmental microbiology.

21. Graham DW, Olivares-Rieumont S, Knapp CW, Lima L, Werner D, et al. (2010) Antibiotic resistance gene abundances associated with waste discharges to the Almendares River near Havana, Cuba. Environ Sci Technol 45(2): 418-424.

22. Rodriguez-Mozaz S, Chamorro S, Marti E, Huerta B, Gros M, et al. (2015) Occurrence of antibiotics and antibiotic resistance genes in hospital and urban wastewaters and their impact on the receiving river. Water Res 69: 234-242.

23. Rizzo L, Manaia C, Merlin C, Schwartz T, Dagot C, et al. (2013) Urban wastewater treatment plants as hotspots for antibiotic resistant bacteria and genes spread into the environment: A review. Sci Total Environ 447: 345-360.

24. Tennstedt T, Szczepanowski R, Braun S, Pühler A, Schlüter A (2003) Occurrence of integron-associated resistance gene cassettes located on antibiotic resistance plasmids isolated from a wastewater treatment plant. FEMS Microbiol Ecol 45(3): 239-252.

25. Zhang T, Zhang XX, Ye L (2011) Plasmid metagenome reveals high levels of antibiotic resistance genes and mobile genetic elements in activated sludge. PloS One 6(10): e26041.

26. LaPara TM, Burch TR, McNamara PJ, Tan DT, Yan M, et al. (2011) Tertiarytreated municipal wastewater is a significant point source of antibiotic resistance genes into Duluth-Superior Harbor. Environmental science \& technology 45(22): 9543-9549.

27. Lee J, Shin SG, Jang HM, Kim YB, Lee J, et al. (2017) Characterization of antibiotic resistance genes in representative organic solid wastes: Food waste-recycling wastewater, manure, and sewage sludge. Science of the Total Environment 579: 1692-1698.

28. Schlüter A, Szczepanowski R, Pühler A, Top EM (2007) Genomics of IncP-1 antibiotic resistance plasmids isolated from wastewater treatment plants provides evidence for a widely accessible drug resistance gene pool. FEMS Microbiol Rev 31(4): 449-477.

29. Pruden A, Arabi M, Storteboom HN (2012) Correlation between upstream human activities and riverine antibiotic resistance genes. Environ Sci Technol 46(21): 11541-11549.

30. Storteboom H, Arabi M, Davis JG, Crimi B, Pruden A (2010) Tracking antibiotic resistance genes in the South Platte River basin using molecular signatures of urban, agricultural, and pristine sources. Environmental science \& technology 44(19): 7397-7404.

31. McKinney CW, Pruden A (2012) Ultraviolet disinfection of antibiotic resistant bacteria and their antibiotic resistance genes in water and wastewater. Environ Sci Technol 46(24): 13393-13400.

32. Mohapatra DP, Brar SK, Tyagi RD, Surampalli RY (2010) Physicochemical pre-treatment and biotransformation of wastewater and wastewater Sludge Fate of bisphenol A. Chemosphere 78(8): 923-941.

33. Park SJ, Chin SS, Jia Y, Fane AG (2010) Regeneration of PAC saturated by bisphenol A in PAC/TiO2 combined photocatalysis system. Desalination 250(3): 908-914.

34. Torres-Palma RA, Nieto JI, Combet E, Pétrier C, Pulgarin C (2010) An innovative ultrasound, $\mathrm{Fe} 2+$ and $\mathrm{TiO} 2$ photoassisted process for bisphenol a mineralization. Water Research 44(7): 2245-2252.
35. Castiglioni S, Bagnati R, Fanelli R, Pomati F, Calamari D, et al. (2005) Removal of Pharmaceuticals in Sewage Treatment Plants in Italy. Environ Sci Technol 40(1): 357-363.

36. Zhao J, Li Y, Zhang C, Zeng Q, Zhou Q (2008) Sorption and degradation of bisphenol A by aerobic activated sludge. J Hazard Mater 155(1-2): 305-311.

37. Tambosi JL, de Sena RF, Favier M, Gebhardt W, José HJ, et al. (2010) Removal of pharmaceutical compounds in membrane bioreactors (MBR) applying submerged membranes. Desalination 261(1-2): 148156.

38. Snyder SA, Adham S, Redding AM, Cannon FS, DeCarolis J, et al. (2007) Role of membranes and activated carbon in the removal of endocrine disruptors and pharmaceuticals. Desalination 202(1-3): 156-181.

39. Cooper WJ, Snyder S (2010) Rate constants and mechanisms of advanced oxidation processes for water reuse. WateReuse Foundation Report, pp. 1-52.

40. Jackson J, Sutton R (2008) Sources of endocrine-disrupting chemicals in urban wastewater, Oakland, CA. Sci Total Environ 405(1-3): 153-160.

41. Husain Q Qayyum S (2013) Biological and enzymatic treatment of bisphenol A and other endocrine disrupting compounds: a review. Crit Rev Biotechnol 33(3): 260-292.

42. Staples CA, Dome PB, Klecka GM, Oblock ST, Harris LR (1998) A review of the environmental fate, effects, and exposures of bisphenol A. Chemosphere 36(10): 2149-2173.

43. Szpyrkowicz L, Juzzolino C, Kaul SN (2001) A Comparative study on oxidation of disperse dyes by electrochemical process, ozone, hypochlorite and fenton reagent. Water Res 35(9): 2129-2136.

44. Hsieh SC, Lin PY (2012) FePt nanoparticles as heterogeneous Fenton-like catalysts for hydrogen peroxide decomposition and the decolorization of methylene blue. Journal of Nanoparticle Research 14(6): 956.

45. Pera-Titus M, Garcia-Molina V, Banos MA, Gimenez J, Esplugas S (2004) Degradation of chlorophenols by means of advanced oxidation processes: a general review. Appl Catal B-Environ 47(4): 219-256.

46. Lucas MS, Peres JA (2006) Decolorization of the azo dye Reactive Black 5 by Fenton and photo-Fenton oxidation. Dyes and Pigments 71(3): 236-244.

47. Minero C, Lucchiari M, Vione D, Maurino V (2005) Fe(III)-enhanced sonochemical degradation of methylene blue in aqueous solution. Environmental Science \& Technology 39(22): 8936-8942.

48. Pignatello JJ, Oliveros E, MacKay A (2006) Advanced oxidation processes for organic contaminant destruction based on the Fenton reaction and related chemistry. Critical Reviews in Environmental Science and Technology 36(1): 1-84.

49. Thakare SR (2004) Catalytic degradation of methylene blue by Fenton like system: model to the environmental reaction. J Environ Sci 16(2): 285-287.

50. Ioan I, Wilson S, Lundanes E, Neculai A (2007) Comparison of Fenton and sono-Fenton bisphenol A degradation. J Hazard Mater 142(1-2): 559-563.

51. Katsumata H, Kawabe S, Kaneco S, Suzuki T, Ohta K (2004) Degradation of bisphenol A in water by the photo-Fenton reaction. Journal of Photochemistry and Photobiology A: Chemistry 162(2): 297-305.

52. Liu ZH, Kanjo Y, Mizutani S (2009) Removal mechanisms for endocrine disrupting compounds (EDCs) in wastewater treatment - physical means, biodegradation, and chemical advanced oxidation: A review. Sci Total Environ 407(2): 731-748.

53. Pisoschi AM, Pop A (2015) The role of antioxidants in the chemistry of oxidative stress: A review. Eur J Med Chem 97: 55-74. 
54. Sharma VK, Johnson N, Cizmas L, McDonald TJ, Kim H (2016) A review of the influence of treatment strategies on antibiotic resistant bacteria and antibiotic resistance genes. Chemosphere 150: 702-714.

55. Guo MT, Yuan QB, Yang J (2015) Distinguishing effects of ultraviolet exposure and chlorination on the horizontal transfer of antibiotic resistance genes in municipal wastewater. Environ Sci Technol 49(9): 5771-5778.

56. Zhuang Y, Ren H, Geng J, Zhang Y, Zhang Y, et al. (2015) Inactivation of antibiotic resistance genes in municipal wastewater by chlorination, ultraviolet, and ozonation disinfection. Environ Sci Pollut Res Int 22(9): 7037-7044.

57. Huang X, Liu C, Li K, Su J, Zhu G, et al. (2015) Performance of vertical up-flow constructed wetlands on swine wastewater containing tetracyclines and tet genes. Water Res 70: 109-117.

58. Liu L, Liu YH, Wang Z, Liu CX, Huang X, et al. (2014) Behavior of tetracycline and sulfamethazine with corresponding resistance genes from swine wastewater in pilot-scale constructed wetlands. J Hazard Mater 278: 304-310.

\begin{tabular}{l} 
Your next submission with Juniper Publishers \\
will reach you the below assets \\
- Quality Editorial service \\
- Swift Peer Review \\
- Reprints availability \\
- E-prints Service \\
- Manuscript Podcast for convenient understanding \\
- Global attainment for your research \\
- Manuscript accessibility in different formats \\
( Pdf, E-pub, Full Text, Audio) \\
- Unceasing customer service \\
Track the below URL for one-step submission \\
https://juniperpublishers.com/online-submission.php \\
\hline
\end{tabular}

